\title{
Does a relationship exist between the number of training or competition hours and the presence of sonographic alterations in the shoulder of CrossFit athletes?
}

\section{¿Existe relación entre la acumulación de horas de entrenamiento o competición con la presencia de alteraciones ecográficas y dolor en el hombro en el deportista de CrossFit?}

\author{
Claudia Juan Vigar ${ }^{1}$ Francesc Medina-Mirapeix ${ }^{2}$ \\ ${ }^{1}$ Centro de Fisioterapia Claudia Juan - Fisioterapia Invasiva, Málaga, Spain \\ 2 Departamento de Fisioterapia, Universidad de Murcia, Murcia, Spain \\ Address for correspondence Claudia Juan Vigar, Centro de \\ Fisioterapia Claudia Juan - Fisioterapia Invasiva, C/ Rodeo SS, Málaga, \\ Spain (e-mail: claudiajuanvigar@gmail.com).
} Rev Fisioter Invasiva 2019;2:9-17.

\begin{abstract}
Introduction CrossFit is a sport that is on the rise and has a known injury rate thanks to studies that have affirmed that the shoulder is the area that suffers the most damage. To date, no objective tool has been used to evaluate this. The aim of the present study was to determine the frequency of structural sonographic alterations in Crossfit athletes and its relationship with accumulated hours of practice and/or competition in the sport and shoulder pain.

Material and Methods A cross-sectional descriptive study was conducted with sonographic assessments performed on 208 shoulders of 104 participants at official CrossFit gyms in Barcelona, between April and May 2017. The participants were requested to complete a specific questionnaire on CrossFit sports practice that included demographic data, the existence of pain, data on training routines, and clinical history. Ultrasound (US) examinations were made on the supraspinatus tendons (SST), on the long head of the biceps (LHB), and on the acromioclavicular (AC) joint. Results The presence of focal hypoechoic areas (FHAs) in the LHB (48.1\%) and in the SST $(60.6 \%)$ were the most common alterations in this sample, whereas, at the level of the AC joint, the most common disorder was the presence of cortical defects (30.3\%). Shoulder pain was present in $37.5 \%$ of the participants. The probability of experiencing pain increased when the athletes accumulated $>1,000$ hours of training (odds ratio $[O R]=2.0)$. In these athletes, the probability of presenting a focal hypoechoic area (FHA) decreased in the LHB (OR $=0.3)$, and the width of the SST increased a mean of

\section{Keywords}

- Crossfit

- shoulder

- musculoskeletal ultrasound

- rotator cuff

- tendon $0.5 \mathrm{~mm}(p<0.01)$. In athletes who participated in competitions, the sonographic pattern also presented an increased width of the SST and LHB tendons; however, this was not related with an increased probability of experiencing pain.

Conclusions The sonographic pattern of the shoulder of CrossFit athletes presented structural changes in the SST and LHB tendons when subjects accumulated $>1,000$ hours of training or when they participated in competitions. It is essential to relate the sonographic findings with the clinical findings of a patient to define whether these findings
\end{abstract}

DOI https://doi.org/ 10.1055/s-0039-1681106. ISSN 2386-4591.
Copyright $\odot 2019$ by Thieme Revinter Publicações Ltda, Rio de Janeiro, Brazil
License terms

() (1) $\odot \circledast$ 


\section{Resumen}

\author{
Palabras clave \\ - crossfit \\ - hombro \\ - ecografía \\ musculoesquelética \\ - manguito rotador \\ - tendón
}

are, indeed, pathological. The probability of experiencing pain in the shoulder doubles when $>1,000$ hours of CrossFit training are accumulated. This finding bears no relation with competing.

Introducción El CrossFit es un deporte en auge del que se conoce su tasa de lesiones gracias a estudios que afirman que la zona más frecuentemente lesionada es el hombro. Hasta el momento no se ha utilizado una herramienta objetiva para evaluarlo. El objetivo de este estudio es determinar la frecuencia de las alteraciones estructurales ecográficas en deportistas de CrossFit y su relación con las horas acumuladas de práctica y/o competición en dicho deporte y con el dolor en el hombro.

Material y Métodos Se realizó un estudio descriptivo transversal en el que se llevaron a cabo evaluaciones ecográficas de 208 hombros de 104 sujetos en 13 gimnasios oficiales de CrossFit en Barcelona entre abril y mayo de 2017. Se les pidió que rellenaran un cuestionario específico de CrossFit con datos demográficos, existencia de dolor, datos sobre sus rutinas de entrenamiento y de sus historias clínicas. Ecográficamente se examinaron los tendones del supraespinoso (TSE), de la porción larga del bíceps (TCLB), y la articulación acromioclavicular (AC).

Resultados Las áreas focales hipoecoicas (AFH) en el TCLB $(48,1 \%$ ) y en el TSE $(60,6 \%)$, fueron las alteraciones más frecuentes, mientras que en la $A C$ la alteración más frecuente fue la presencia de defectos corticales (30,3\%). El dolor en el hombro estaba presente en un 37,5\%. La probabilidad de tener dolor se incrementa $(O R=2,0)$ cuando los deportistas acumulan más de 1.000 horas de entrenamiento. En esos deportistas, decrece la probabilidad de presentar AFH $(O R=0,3)$ en el TCLB y aumenta el grosor del TSE en una media de $0,5 \mathrm{~mm}(\mathrm{p}<0,01)$. En los deportistas que participaban en competiciones, el patrón ecográfico también presentó un aumento del grosor en los tendones de TSE y TCLB, pero no se relacionó con un aumento en la probabilidad de tener dolor.

Conclusiones El patrón ecográfico de hombro de los deportistas de CrossFit presentó cambios estructurales en los tendones TSE y TCLB cuando acumulaban más de 1.000 horas de entrenamiento o cuando participaban en competiciones. Es imprescindible relacionar los hallazgos ecográficos con la clínica del paciente para definir si son patológicos o no. La probabilidad de tener dolor en el hombro se duplica cuando se acumulan más de 1.000 horas de entrenamiento de CrossFit y no guarda relación con el hecho de competir.

\section{Introduction}

CrossFit is a training program created in 1995 by Greg Galssman. ${ }^{1}$ Over the recent years, > 12,000 gyms worldwide offer these programs. ${ }^{2}$ The aim of this training method is to prepare athletes for any type of unknown or unexpected exertion. $^{3}$ For this reason, a wide variety of functional exercises are incorporated, which involve the displacement of large loads, rapidly and over long distances, in which exercises are combined to create varied circuits executed at high intensity. ${ }^{3}$ Furthermore, CrossFit has been shown to improve physical capacities, such as the body mass index (BMI), the muscular resistance, and the aerobic capacity. ${ }^{1,4,5}$

A number of studies have analyzed the injuries associated with the practice of this sport with the aim of identifying the rate of injuries, the most frequent injury locations, and the associated risk factors. Although different studies have identified that vascular injuries occur associated with CrossFit, 6,7 these are not common. The musculoskeletal system is the site of most injuries, with studies showing that per each 1,000 hours of training, the injury rate varies from 2.1 to $3.1 .^{2,8,9}$ Regarding the location of injuries, according to current research, the shoulder area is the most frequently injured area. ${ }^{8-10}$ Other less frequent locations of reported injuries are the lumbar area and the knees. ${ }^{10}$

Concerning risk factors, the following have been identified to date: demographic characteristics, training habits, characteristics of the sports centers, ${ }^{11}$ and the performance of specific exercises, such as the overhead press, the snatch and the kipping pull up ${ }^{12}$ (the latter in the case of shoulder injuries).

Until now, the definition of injury used was based on the amount of time that the pain kept the athlete away from training 
and/or forced them to adapt training. The majority of past studies used self-report questionnaires, completed by the athletes to determine the location of the musculoskeletal injuries. The associated use of clinical or complementary image sources has been very low, and no studies have used ultrasound (US) to characterize or examine structural alterations associated with injuries reported in CrossFit, nor for analyzing whether relevant preclinical structural changes exist among these athletes.

Musculoskeletal US has demonstrated to be one of the most reliable, diagnostically accurate tools for evaluating the shoulder joint, with the advantage of being noninvasive, having no ionizing effects, and offering real-time imaging of structures. ${ }^{13}$ The results of one of the latest literature reviews are of high sensitivity and specificity in the diagnosis of partial rotator cuff ruptures, of tendinous calcifications, of luxation of the long head of the biceps brachialis (LHB), and of subacromial bursitis. ${ }^{14}$ However, until now, these structural changes have never been documented in the CrossFit athlete.

Our hypothesis is that a practice load of $>1,000$ hours, accumulated during the life of the athlete, is associated with the presence of structural changes in the tendons and in other structures of the shoulder.

Therefore, the main aim of the present study was to determine the frequency of sonographic structural disorders in CrossFit athletes and its relationship with the accumulated hours of practice of the sport. The following secondary aims were established: to determine whether consistency exists in the relationship between having shoulder pain and accumulated practice of $>1,000$ hours of CrossFit and/or due to competitive training, and to describe the frequency of structural disorders in the shoulder via US.

\section{Material and Methods}

\section{Study Design and Participants}

A descriptive-analytical cross-sectional study was performed. Eight voluntary athletes were recruited from each of the 13 official CrossFit gyms selected in Barcelona, Spain. The inclusion criteria consisted of being an active CrossFit athlete aged between 18 and 65 years old at the time of recruitment. The exclusion criteria were athletes recovering from a surgical intervention or shoulder fracture, or who had a medical diagnosis of adhesive capsulitis or of rupture of the complete width of the rotator cuff.

The Research Ethics Committee (CEI, in the Spanish acronym) of the CEU San Pablo University approved the study, which fulfilled all the principles established in the Declaration of Helsinki.

A physiotherapist with $>5$ years of experience in the performance and interpretation of sonographic images assessed the eligibility criteria. All subjects included in the present study signed the corresponding informed consent. The same researcher gathered information of the demographic and clinical variables, plus those variables related to the sports practice (via a heteroadministrated questionnaire). As the study unit was the shoulder, not the athlete, the sonographic and clinical information were gathered for both shoulders of each athlete.

\section{Clinical Variables}

The presence of pain was measured as a dichotomous variable (symptomatic/asymptomatic), and the presence of disorders was evaluated at the level of the long head of the biceps tendon (LHB), of the supraspinatus tendon (SST), and of the acromioclavicular joint (AC). These structures were selected as they are frequently injured during weight lifting. ${ }^{15}$ A sonographic exam protocol was defined to identify three structural alterations in the LHB (presence of liquid in the sheath, instability of the LHB, focal hypoechoic areas (FHAs), and hyperechoic images compatible with calcifications), four in the SST (presence of liquid in the subacromial bursa, cortical defects of the humerus, focal hypoechoic areas, and calcifications) and two in the AC joint (cortical defects, and synovial alterations).

The US device used was a Sonosite M-Turbo (Fujifilm, Tokyo, Japan) with a linear probe of between 6 and $15 \mathrm{MHz}$ and a constant depth of $4 \mathrm{~cm}$ for performing measurements. The participant was placed in a seated position on a stool with the feet on the floor, the back straight, and looking straight ahead. The evaluated upper limb was placed with the elbow at $90^{\circ}$ flexion, neutral pronosupination, and the subjects were asked to hold the wrist with the other hand (-Fig. 1). The examiner, seated on the side of the shoulder to be assessed, was in front of the patients, with the equipment facing them. ${ }^{13,16,17}$ The probe was placed upon the anterior aspect of the shoulder, perpendicular to the LHB. A scan was performed from proximal to distal, visualizing the tendon within the bicipital groove. ${ }^{13,17}$ At the level of the proximal aspect of the shoulder, the intra-articular portion was identified, where the tendon becomes horizontal in order to course within the joint, changing the direction of its laminar pattern. ${ }^{16}$ Within the bicipital groove, the tendon presents an oval shaped and slanted image

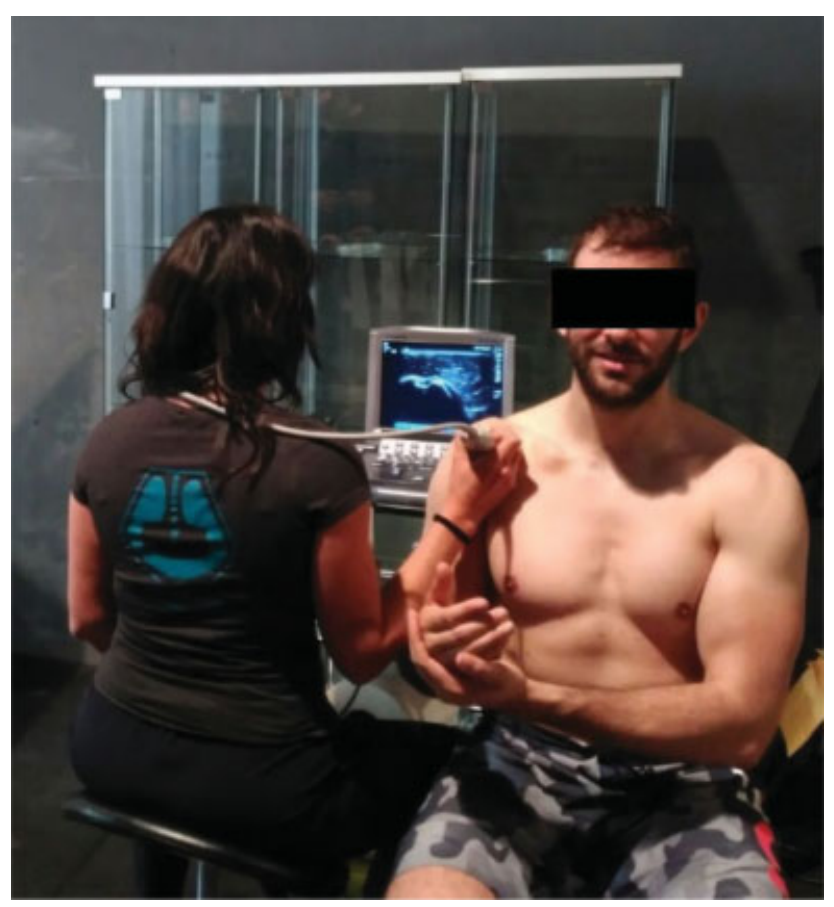

Fig. 1 Initial position of the patient and of the examiner for the sonographic shoulder assessment protocol. 
as, in the medial portion, it is supported by the semicircular humeral ligament, which is formed by fibers of the coracohumeral ligament $(\mathrm{CHL})$ and of the superior glenohumeral ligament (SGHL). ${ }^{18,19}$ During the scan, the probe was placed in the transverse plane and measurements of the width of the LHB were made, calculating the distance between the perpendicular axis to the line of its maximum diameter, passing through its medial point (-Fig. 2a) ${ }^{20}$ The examiner then descended the probe until assessing the most distal area of the tendon in the myotendinous junction, where the image of a longitudinal tendon section of the pectoralis major appears. In this area, synovial liquid tends to accumulate ${ }^{17}$ (liquid in the sheath) which was classified as being positive when the anechoic image surrounding the tendon measured $>2 \mathrm{~mm}^{2}$.

The probe was then moved upwards again and passive external shoulder rotation was performed to evaluate the instability of the LHB in its groove; this was defined as being positive when the tendon was displaced medially on top of the lesser tubercle of the humerus. ${ }^{16}$

The probe was displaced laterally and was evaluated in a transverse section of the SST. The patient was asked to place the palm of the hand on the anterosuperior iliac crest with the elbow flexed behind the midline. ${ }^{21}$ The SST was visualized as hyperechoic and fibrillary on the anechoic humeral cartilage. The width was measured based on a cross-sectional section, in the midarea of the tendon, $12,5 \mathrm{~mm}$ lateral to the $\mathrm{LHB},{ }^{17,22}$ (-Fig. 2). The lower limit of the measurement was the first homogenous hyperechoic region upon the anechoic joint cartilage of the head of the humerus, and the superior limit was the edge of the tendon before the hyperechoic line of the subacromial bursa. ${ }^{13}$ Also, using a longitudinal section, we have evaluated the presence of liquid content in the subacromial bursa (liquid in the subacromial bursa), which was positive when the width of the anechoic image of the liquid was $>2 \mathrm{~mm}^{2}$.

Focal hypoechoic areas and the presence of hyperechoic areas compatible with calcifications in the LHB and in the SST were evaluated and compared in both transverse and longitudinal sections.

Finally, the AC joint was evaluated by placing the probe upon the superior aspect of the shoulder, on the coronal plane, with the arm in neutral position hanging alongside the body. At this point, the presence of cortical bone defects was evaluated (cortical AC defects) and the presence of structural disorders in the capsuloligamentous tissue was defined when the capsular distension of the AC joint (synovial alterations) was $>3 \mathrm{~mm}^{17,20}$

Following the methodology employed by other authors, ${ }^{21}$ before gathering sonographic images, an intraobserver reliability study was performed with one of the US measurements made (the width of the SST), and assuming that the same reliability could be applicable to others. For the present study, the examiner repeated the measurements twice, separated by an interval of between 48 and 72 hours, to a total of 10 shoulders of five CrossFit athletes. The reliability obtained was excellent, with an intraclass correlation coefficient (ICC) of 0.977 .

\section{Demographic Variables and Sports Related Variables}

The sociodemographic variables of gender and age (years old) were gathered, as well as the variables regarding two lifestyle aspects, such as the type of current work (sedentary/ active) and sports practice prior to beginning CrossFit (if these involved efforts related with the shoulder) with a dichotomous yes/no answer.

The variables regarding CrossFit practice included participation in competitions, years of CrossFit practice, number of weekly training sessions, and duration of training (hours). Based on these last 3 variables, the number of accumulated hours over the recent years was calculated and the result was split into 2 categories ( $>1,000$ accumulated hours, and $<1,000$ accumulated hours).

\section{Statistical Analysis}

IBM SPSS Statistics for Windows, Version 24.0 (IBM Corp., Armonk, NY, USA) was used. A descriptive analysis of the sample was performed displaying the mean \pm standard deviation (SD) for the quantitative variables and the percentage for the qualitative variables. The intraobserver reliability was determined using the ICCs. The study of the independence of qualitative variables was performed using the chisquared test or, in its defect, the Fisher exact test, according

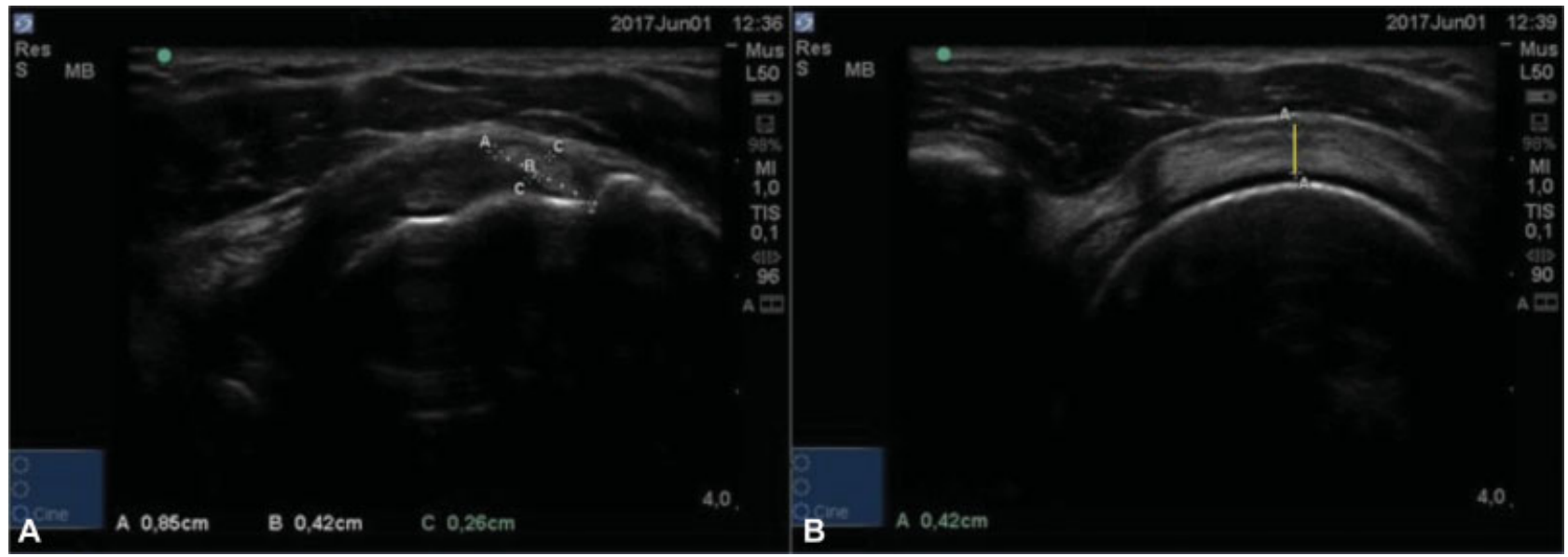

Fig. 2 A -Measurement of the width of the LHB (a: maximum diameter of the LHB; b: midpoint of the diameter of the LHB; : width of the LHB). B-Measurement of the width of the supraspinatus tendon. Abbreviaton: LHB, tendon of the long head of biceps. 
to the fulfillment of the corresponding criteria. To compare means among groups of pairs, the Student- $t$ test was used for independent samples.

To establish the relationship between the accumulated hours of training, the presence of pain or other alterations and the width of the tendons, multiple logistic regression models were used, analyzing each of the alterations as dependent variables. These were executed initially without adjusting these variables, and then adjusting them for the following variables: age, sedentary work, and the performance of previous sports related with the shoulder. At all times, a p-value $<0.05$ was established, with a $95 \%$ confidence interval $(\mathrm{CI})$.

\section{Results}

\section{Characteristics of the Participants}

In total, 104 subjects were included ( $71 \%$ men) with a mean age of 33.8 years old $(S D=8.2)$. Before beginning CrossFit practice, $80.8 \%$ had not practiced any type of sport involving the shoulder. At the time of the study, 25.9\% had accumulated $>1,000$ hours of practice, and $29.8 \%$ had already competed regularly ( - Table $\mathbf{1}$ ). Athletes with $>1,000$ accumulated hours had a similar sociodemographic profile to the remaining participants; however, they competed sig- nificantly more. Those who competed trained significantly more hours than those who did not.

\section{Frequency of Pain and Structural Alterations}

In total, 208 shoulders were examined (of 104 subjects). The frequency of pain in the shoulder was of $37 \%$ (-Table 2 ). The most frequent structural alteration related with the LHB was the presence of FHAs (48.1\%), as occurred in the case of SST (60.6\%), while, in the case of the AC joint, the most common structural alteration were cortical defects (30.3\%). The less frequent alterations were liquid in the subacromial bursa, instability of the LHB, and calcifications of the LHB. Out of the total shoulders examined, 105 were dominant shoulders, since one subject was ambidextrous. Both the pain, as well as all of the structural alterations found, were homogenously distributed between the dominant and nondominant sides, with nonsignificant $p$-values (-Table $\mathbf{2}$ ). For this reason, we have decided to explore these together in the subsequent analyses, which were directed at exploring their relationship with the accumulated hours of practice.

\section{Relation with Accumulated Hours of CrossFit Practice} The univariate logistic regression models (nonadjusted) showed that having (or not) $>1,000$ accumulated hours of

Table 1 Characteristics of the participants (in total and by subgroups of hours of practice)

\begin{tabular}{|c|c|c|c|c|c|c|}
\hline \multicolumn{2}{|c|}{ Characteristics } & \multirow{2}{*}{$\begin{array}{l}\text { Total } \\
(n=104)\end{array}$} & \multicolumn{2}{|c|}{ Accumulates $>1,000 \mathrm{~h}$} & \multicolumn{2}{|l|}{ Competes } \\
\hline & & & $\begin{array}{l}\text { NO } \\
(n=78)\end{array}$ & $\begin{array}{l}\text { YES } \\
(n=26)\end{array}$ & $\begin{array}{l}\text { NO } \\
(n=73)\end{array}$ & $\begin{array}{l}\text { YES } \\
(n=31)\end{array}$ \\
\hline \multicolumn{7}{|c|}{ Demographic characteristics } \\
\hline \multicolumn{2}{|c|}{$\begin{array}{l}\text { Age (years old); } \\
\text { mean } \pm S D\end{array}$} & $33.8 \pm 8.2$ & $34.3 \pm 7.9$ & $31.9 \pm 9.1$ & $34.3 \pm 8.2$ & $32.5 \pm 8.3$ \\
\hline & Male gender & $74(71)$ & & & & \\
\hline & \multicolumn{6}{|l|}{ Lifestyle } \\
\hline & Sedentary work & $55(52.9)$ & $45(57.7)$ & $10(38.5)$ & $41(56.2)$ & $14(45.2)$ \\
\hline $\begin{array}{l}\text { No pr } \\
\text { (relat } \\
\text { shoul }\end{array}$ & $\begin{array}{l}\text { sport } \\
\text { with the } \\
\text { r) }\end{array}$ & $84(80.8)$ & $63(80.8)$ & $21(80.8)$ & $60(80.2)$ & $24(77.4)$ \\
\hline \multicolumn{7}{|c|}{ CrossFit practice } \\
\hline \multicolumn{2}{|c|}{ Competes } & $31(29.8)$ & $14(17.9)$ & $17(65.4)^{* *}$ & - & - \\
\hline \multicolumn{2}{|c|}{$\begin{array}{l}\text { Accumulates }>1,000 \text { h- } \\
\text { ours }\end{array}$} & $26(25)$ & - & - & $9(12.3)$ & $17(54.8)^{* *}$ \\
\hline \multicolumn{2}{|c|}{$\begin{array}{l}\text { Accumulated hours, } \\
\text { mean } \pm S D\end{array}$} & $722 \pm 644$ & $411 \pm 225$ & $1656 \pm 584$ & $499 \pm 437$ & $1248 \pm 746^{* *}$ \\
\hline \multicolumn{2}{|c|}{$\begin{array}{l}\text { Days of training, } \\
\text { mean } \pm S D\end{array}$} & $4.3 \pm 1.2$ & & & & \\
\hline \multicolumn{2}{|c|}{$\begin{array}{l}\text { Hours of training/day, } \\
\text { mean } \pm S D\end{array}$} & $1.4 \pm 0.6$ & & & & \\
\hline \multicolumn{7}{|c|}{ Years of practice } \\
\hline \multicolumn{2}{|l|}{$<1$} & $31(29.8)$ & & & & \\
\hline \multicolumn{2}{|l|}{$1-2$} & $34(32.7)$ & & & & \\
\hline \multicolumn{2}{|l|}{$>2$} & $39(37.5)$ & & & & \\
\hline
\end{tabular}

Abbreviation: SD, standard deviation. The statistics represent the number (\%) of participants of each group, except if another is specified. ${ }^{* *} \mathrm{p}<0.01$. 
Relationship between the Number of Training or Competition Hours and the Presence of Sonographic Alterations

Table 2 Prevalence of pain and structural alterations (total and by sides)

\begin{tabular}{|l|l|l|l|l|}
\hline Variables & $\begin{array}{l}\text { Total Shoulders } \\
(\boldsymbol{n}=\mathbf{2 0 8})\end{array}$ & $\begin{array}{l}\text { Non-dominant shoulders } \\
(\boldsymbol{n}=\mathbf{1 0 3})\end{array}$ & $\begin{array}{l}\text { Dominant shoulders } \\
(\boldsymbol{n}=\mathbf{1 0 5})\end{array}$ & $p$-value \\
\hline Presence of pain & $78(37.5)$ & $35(34)$ & $43(41)$ & 0.299 \\
\hline Alterations related with the LHB & $17(8.2)$ & $8(7.8)$ & $9(8.6)$ & 0.832 \\
\hline Liquid in sheath & $8(3.8)$ & $3(2.9)$ & $5(4.8)$ & 0.734 \\
\hline Instability LHB & $100(48.1)$ & $50(48.5)$ & $50(47.6)$ & 0.894 \\
\hline FHAs & $1(0.5)$ & $1(1)$ & $0(0)$ & 0.992 \\
\hline Calcifications & $0.28 \pm 0.06$ & $0.28 \pm 0.07$ & $0.27 \pm 0.04$ & 0.185 \\
\hline Width (cm), mean \pm SD & & $5(4.8)$ & \\
\hline Alterations related with the SST & $3(2.9)$ & $21(20.0)$ & 0.739 \\
\hline Liquid subacromial bursa & $8(3.8)$ & $14(13.6)$ & $69(65.7)$ & 0.217 \\
\hline Cortical defects humerus & $35(16.8)$ & $57(55.3)$ & $11(10.5)$ & 0.126 \\
\hline FHAs & $126(60.6)$ & $0.53 \pm 0.07$ & 0.498 \\
\hline Calcifications & $19(9.1)$ & & 0.290 \\
\hline Width (cm), mean \pm SD & $0.52 \pm 0.07$ & $0.52 \pm 0.071$ & $28(26.7)$ & \\
\hline Alterations Related with the AC & $51(24.5)$ & $23(22.3)$ & $31(29.5)$ & 0.467 \\
\hline Synovial alterations & $63(30.3)$ & $32(31.1)$ & 0.804 \\
\hline Cortical defects
\end{tabular}

The values represent the number (\%) of participants of each group, unless otherwise specified.

Abbreviations: AC, acromioclavicular joint; FHAs focal hypoechoic areas; LHB, tendon of the long head of biceps; SD, standard deviation; SST, supraspinatus tendon.

practice was only related with the presence of pain and other FHAs in the LHB. In - Table 3, we can see that the odds or the probability of having pain increases (odds ratio $[\mathrm{OR}]=2.0$ ) when the athletes accumulate $>1,000$ hours. The opposite occurs with the odds of presenting FHAs in the LHB, seeing as it decreases $(\mathrm{OR}=0.3)$ among these athletes. The table displays that there were $25.2 \%$ (54.5-28.8) less athletes with FHAs among those who had a greater accumulated load.

The adjusted regression models allowed us to observe that both the ORs of the nonadjusted models and of the adjusted models (with age, sedentary work, and previous shoulder related sports) were maintained at a constant level.

Table 3 Association between accumulating more than 1,000 hours, pain and structural changes

\begin{tabular}{|c|c|c|c|c|}
\hline \multirow[t]{2}{*}{ Variables } & \multicolumn{4}{|c|}{ Accumulates $>1,000 \mathrm{~h}$} \\
\hline & $\begin{array}{l}\text { NO } \\
(n=52)\end{array}$ & $\begin{array}{l}\text { YES } \\
(n=156)\end{array}$ & OR $(95 \% \mathrm{Cl})^{a}$ & OR $(95 \% \mathrm{CI})^{\mathrm{b}}$ \\
\hline Presence of pain & $26(50)$ & $52(33.3)$ & $2.0(1.1-3.8)^{*}$ & $2.0(1.1-3.9)^{*}$ \\
\hline \multicolumn{5}{|l|}{ Alterations related with the LHB } \\
\hline Liquid in the sheath & $6(11.5)$ & $11(7.1)$ & $1.7(0.6-4.9)$ & $2.8(0.9-8.8)+$ \\
\hline FHAs & $15(28.8)$ & $85(54.5)$ & $0.3(0.2-0.7)^{* *}$ & $0.4(0.2-0.8)^{* *}$ \\
\hline \multicolumn{5}{|l|}{ Alterations related with the SST } \\
\hline Cortical defects of humerus & $9(17.3)$ & $26(16.7)$ & $1.0(0.5-2.4)$ & $1.2(0.5-2.8)$ \\
\hline FHAs & 27 (51.9) & $99(63.5)$ & $0.6(0.3-1.2)$ & $0.7(0.4-1.3)$ \\
\hline Calcifications & $4(7.7)$ & $15(9.6)$ & $0.8(0.3-2.5)$ & $0.9(0.3-3.0)$ \\
\hline \multicolumn{5}{|l|}{ Alterations related with the $A C$} \\
\hline Synovial alterations & $17(32.7)$ & $34(21.8)$ & $1.7(0.9-3.5)$ & $1.9(0.9-3.9)+$ \\
\hline Cortical defects & $16(30.8)$ & $47(30.1)$ & $1.0(0.5-2.1)$ & $1.3(0.6-2.8)$ \\
\hline
\end{tabular}

Abbreviations: AC, acromioclavicular joint; $\mathrm{Cl}$, confidence interval; FHAs, focal hypoechoic areas; LHB, tendon of the long head of biceps; OR, odds ratio; SST, supraspinatus tendon.

${ }^{*} p<0.05 ;{ }^{* *} p<0.01 ;+p<0.10$. The values represent the number (\%) of participants in each group, except if another is specified, a- Without adjustment; b- Adjusted by age, sedentary work and previous sport associated with the shoulder. 
No statistically significant differences regarding pain or structural alterations (data not shown) existed between the subjects that competed and those who did not. These findings were consistent both for the adjusted models and the nonadjusted models.

A model of linear regression was performed to analyze the relationship between the average width of the LHB and SST tendons in the subgroup of athletes who had $>$ or $<$ than 1,000 hours and whether or not they competed, with and without adjusting for age, sedentary work, and previous shoulder related sports ( - Table 4 ). In the SST, the relation between accumulated hours and width was significant, with a mean change of $0.5 \mathrm{~mm}$ with $>1,000$ hours, whereas this relationship was not significant in relation to the LHB. However, the fact of competing did have a significant relation with the width of both tendons, which increased by a mean of $0.3 \mathrm{~mm}$ both in the SST, as well as in the LHB, independent of age, sedentary work, and previous sport associated to the shoulder. The fact of competing had no relation with other structural alterations.

\section{Discussion}

This is the first study that has been able to objectively evaluate the characteristics of these lesions by evaluating the predisposition of injuring each tissue using US in order to establish the foundations that enable both physiotherapists and trainers to create a specific prevention plan for this sport. For this reason, we have evaluated the shoulder structures which, according to the study by Kolber et al, ${ }^{16}$ are known to suffer the most during weight lifting sports, such as the LHB, the SST and the AC joint. By examining sonographically these structures, a high prevalence of FHAs are observed in the SST and in the LHB (48.1\% and $60.6 \%$, respectively), as well as many cortical defects in the AC joint (30,3\%). In order to relate the sonographic findings with CrossFit practice, it was necessary to evaluate the relationship between each of these findings and training durations. To date, few articles have focused on examining a possible relation between these factors, while only one study to date has specifically studied the shoulder, ${ }^{12}$ revealing an injury rate of 1.18 for every 1,000 hours of training. A further nonspecific study exists which found an injury rate of 0.51 for every 1,000 hours of training. ${ }^{9}$ The results of our study confirm that the number of hours of training increases the probability of experiencing a shoulder injury; however, it also provides specific information on exactly which shoulder tissues are prone to injury. In this manner, we have observed that CrossFit training specifically affects the SST tendon, leading to an increased width of $0.5 \pm 0.1 \mathrm{~mm}(p<0.01)$ after 1,000 hours of training. According to the study by Michener et al, ${ }^{13}$ a thickening of $0.6 \mathrm{~mm}$ of the SST is related with "subacromial impingement syndrome". Considering this data and the findings of our study, a thickening of $0.5 \mathrm{~mm}$ in CrossFit athletes is not necessarily pathological; however, it does indicate a preclinical change which should be considered in the complexity of the so-called subacromial pain syndrome. Besides, when the SST was evaluated among weightlifting athletes in the study by Setiawati et $\mathrm{al}^{23}$ the practice of this sport was directly related with a greater number of injuries in the SST. Therefore, it is necessary to compare the US image data with the clinical presentation of the patient in order to deduce whether, or not, the thickening is pathological.

Besides the repercussion that CrossFit training has on the shoulder in terms of the increased width of the SST, an adaptation of the LHB is also observed in this sport. We were able to confirm that training times affect the presence of FHA in the LHB, observing how the accumulation of $>1,000$ hours of CrossFit training reduces the FHA in the LHB by half. This makes the time of training factor a protector of the LHB, meaning that the tendon adapts to the training load, which improves its structure of collagen fibers.

Additionally, according to the current literature, there are several factors which could affect this relationship between structural changes and time trained, such as age, the sports history of the participants, or the physical activity performed in their workplace. However, as can be observed in the present study, the age of the athletes did not influence the appearance of structural alterations, that is, being older does not favor the risk of shoulder injury. While this coincides with the study by Summit et al, ${ }^{12}$ it contradicts studies by Weisenthal et al ${ }^{10}$ and by Sprey et al, ${ }^{11}$ who affirmed that age significantly increases the possibilities of suffering an injury. However, it is important to consider that the population of the present study is $<65$ years old. The results of our study do not support the theory by Weisenthal et $\mathrm{al}^{10}$ that states that having practiced some kind of previous sport related with the shoulder increases the probability of suffering an injury.

Concerning the relationship between pain and hours of CrossFit training, we observed that beyond 1,000 accumulated hours of training, the probabilities of suffering shoulder pain are twice fold. Therefore, when the mean number of weekly training hours is multiplied by 52 weeks per year, 1,000 hours of training correspond to 3 years of sports practice. In this manner, we can discard the affirmation by Sprey et al, ${ }^{11}$ which states that, after 2 years of practice, the probability of suffering

Table 4 Relationship between accumulating more than 1,000 hours, competing and the width of tendons

\begin{tabular}{|l|l|l|l|l|l|l|}
\hline & \multicolumn{4}{l|}{ Accumulates $>1,000 \mathrm{~h}$} & \multicolumn{2}{l|}{ Competes } \\
\hline & NO & YES & Mean change (SE) & NO & YES & Mean change (SE) $^{\text {a }}$ \\
\hline Width LHB $(\mathrm{mm})$ & $2.8 \pm 0.6$ & $2.9 \pm 0.4$ & $0.1(0.1)$ & $2.7 \pm 0.4$ & $3.0 \pm 0.8$ & $0.3(0.1)^{* *}$ \\
\hline Width SST $(\mathrm{mm})$ & $5.1 \pm 0.7$ & $5.6 \pm 0.8$ & $0.4(0.1)^{* *}$ & $5.1 \pm 0.6$ & $5.4 \pm 0.8$ & $0.3(0.1)^{* *}$ \\
\hline
\end{tabular}

Abbreviations: LHB: tendon of the long head of biceps; SE, standard error; SST: supraspinatus tendon. ${ }^{\text {a }}$ - Increase in the mean width because of having 1,000 hours of practice adjusted by age, sedentary work and previous shoulder related sports. ${ }^{* *} p<0.01$. 
an injury increases by $44.9 \%(p=0.013)$; as well as studies by Weisenthal et $\mathrm{al}^{10}$ regarding the absence of a relationship between hours of training and injury risk.

Furthermore, we have evaluated the relation between pain and competition and whether competing ${ }^{9,11}$ increases the risk of injury. This is the first study that objectively demonstrates that CrossFit training does not increase the probability of suffering shoulder pain, by observing that pain is related with a greater number of hours of training but not to the effects of competing per se. However, the fact that competing does not provoke shoulder pain does not mean that structural changes do not occur in the joint. In the present study, we have observed that the SST and the LHB thickened by $0.3 \pm 0.1 \mathrm{~mm}(p<0.01)$ compared with athletes who did not compete, although, as has been previously commented, these sonographic findings must always be related with the clinical presentation of the athlete. Concretely, in the case of the LHB, the study by Chang et $\mathrm{al}^{20}$ affirms that a thickening of $0.2 \mathrm{~mm}$ could be related with pathology. However, if we consider the decrease of the FHA of the LHB that occurs in CrossFit athletes who accumulate $>1,000$ hours of training, we may think that the thickening of the tendon is an adaptation to the sport. Besides, in a study performed on volleyball athletes, ${ }^{21}$ the authors conclude that the thickening of the LHB $>0.6 \mathrm{~mm}$ $(p<0.01)$ is related with pathology.

Finally, we have observed that demographic characteristics and the lifestyle of athletes who had accumulated $>1,000$ hours of training were similar to those of athletes who accumulated fewer hours, with the only difference being their participation in competitions. Besides, $80.8 \%$ of the athletes evaluated had not practiced any prior shoulder related sport, with CrossFit being the first sports activity in which this joint was more specifically involved. As affirmed in the study by Summit et $\mathrm{al}^{12}$ the CrossFit exercises that cause the most injury to the shoulder are the overhead press $(28,2 \%)$, the snatch $(21,7)$ and the kipping pull up $(10.8 \%)$. This coincides with the overhead position, which compromises the structures evaluated in the present study and in which we have observed that structural changes take place. Therefore, these sonographic findings may be useful both for appropriately identifying the target tissue when performing US-guided invasive physical therapy treatments, as well as for recommending the restriction of certain exercises that involve the overhead position during the progression of treatment in injuries to the tissues of the SST, of the LHB and of the AC joint. Besides, this would help support the recommendation that these treatments should be accompanied by exercises for increasing strength and mobility (increasing mobility in interior rotation ${ }^{24}$ ), to increase the subacromial space with the aim of decreasing the consequences of the thickening of the SST and of the LHB.

\section{Study Limitations}

The present study presents several limitations, such as the fact that people with symptomatic shoulders or those who have suffered another injury were more interested in receiving sonographic assessments when compared to healthy subjects.
Another limitation was that, during the sonographic examinations, the subjects came both before and immediately after training. In certain cases, this may have modified the sonographic findings. Furthermore, the injured subjects with major structural alterations that prevented them from training normally did not go to gyms and, therefore, do not appear to be a representative sample.

\section{Future Lines of Research}

It would be interesting to perform future research focused on relating sonographic alterations with orthopedic tests to confirm whether the pain experienced in symptomatic shoulders corresponds to the tissue in which the structural alterations are located.

\section{Conclusions}

The most frequent structural alterations in CrossFit athletes are FHAs of the SST and of the LHB tendons and cortical defects in the AC.

After 1,000 hours of training, we can observe a significant increase in the width of the SST, of $0.5 \pm 0.1 \mathrm{~mm}$, and a significant decrease in the FHAs of the LHB.

The probability of suffering pain in the shoulder duplicates when $>1,000$ hours of CrossFit are reached, and there is no relationship with the fact of training.

The difference in the sonographic examination of the shoulder among competitors and noncompetitors is the increased width of $0.3 \pm 0.1 \mathrm{~mm}$ in the SST and LHB tendons.

Conflict of Interest

The author has no conflict of interest to declare.

\section{References}

1 Paine J, Uptgraft J, Wylie R. CrossFit study. CGSC 2010:1-34

2 Moran S, Booker H, Staines J, Williams S. Rates and risk factors of injury in CrossFitTM: a prospective cohort study. J Sports Med Phys Fitness 2017;57(09):1147-1153

3 CrossFit. The CrossFit training guide. 2016; Available at: http:// www.crossfit.com/cf-seminars/CertRefs/CF_Manual_v4.pdf. Accessed February 26, 2017

4 Barfield J, Anderson A. Effect of CrossFit ${ }^{\mathrm{TM}}$ on Health-related Physical Fitness: A Pilot Study. J Strength Cond Res 20142(1):

5 Smith MM, Sommer AJ, Starkoff BE, Devor ST. Crossfit-based highintensity power training improves maximal aerobic fitness and body composition. J Strength Cond Res 2013;27(11):3159-3172

6 Hadeed MJ, Kuehl KS, Elliot DL, Sleigh A. Exertional rhabdomyolysis after CrossFit exercise program. Med Sci Sports Exerc 2011; 45(05):224-225

7 Bergeron MF, Nindl BC, Deuster PA, et al. Consortium for Health and Military Performance and American College of Sports Medicine consensus paper on extreme conditioning programs in military personnel. Curr Sports Med Rep 2011;10(06):383-389

8 Hak PT, Hodzovic E, Hickey B. The nature and prevalence of injury during CrossFit training. J Strength Cond Res 2013

9 Montalvo AM, Shaefer H, Rodriguez B, Li T, Epnere K, Myer GD. Retrospective Injury Epidemiology and Risk Factors for Injury in CrossFit. J Sports Sci Med 2017;16(01):53-59

10 Weisenthal BM, Beck CA, Maloney MD, DeHaven KE, Giordano BD. Injury Rate and Patterns Among CrossFit Athletes. Orthop J Sports Med 2014;2(04):2325967114531177 
11 Sprey JW, Ferreira T, de Lima MV, Duarte A Jr, Jorge PB, Santili C. An Epidemiological Profile of CrossFit Athletes in Brazil. Orthop J Sports Med 2016;4(08):2325967116663706

12 Summitt RJ, Cotton RA, Kays AC, Slaven EJ. Shoulder Injuries in Individuals Who Participate in CrossFit Training. Sports Health 2016;8(06):541-546

13 Michener LA, Subasi Yesilyaprak SS, Seitz AL, Timmons MK, Walsworth MK. Supraspinatus tendon and subacromial space parameters measured on ultrasonographic imaging in subacromial impingement syndrome. Knee Surg Sports Traumatol Arthrosc 2015;23(02):363-369

14 Henderson RE, Walker BF, Young KJ. The accuracy of diagnostic ultrasound imaging for musculoskeletal soft tissue pathology of the extremities: a comprehensive review of the literature. Chiropr Man Therap 2015;23(01):31

15 Kolber MJ, Beekhuizen KS, Cheng MS, Hellman MA. Shoulder injuries attributed to resistance training: a brief review. J Strength Cond Res 2010;24(06):1696-1704

16 Benítez Pareja D, Trinidad Martín-Arroyo J, Benítez Pareja P, Torres Morera L. Estudio e intervencionismo ecoguiado de la articulación del hombro. Rev Soc Esp Dolor 2012;19(05):264-272

17 Mantilla R, Vega AF, Rodríguez R. Ecografía de hombro: una alternativa en el diagnóstico de las rupturas del manguito rotador. Rev Medica Sanitas 2014;17(02):82-93
18 Itoigawa Y, Itoi E. Anatomy of the capsulolabral complex and rotator interval related to glenohumeral instability. Knee Surg Sports Traumatol Arthrosc 2016;24(02):343-349

19 Jost B, Koch PP, Gerber C. Anatomy and functional aspects of the rotator interval. J Shoulder Elbow Surg 2000;9(04):336-341

20 Chang KV, Chen WS, Wang TG, Hung CY, Chien KL. Quantitative ultrasound facilitates the exploration of morphological association of the long head biceps tendon with supraspinatus tendon full thickness tear. PLoS One 2014;9(11):e113803

21 Leong HT, Tsui S, Ying M, Leung VY, Fu SN. Ultrasound measurements on acromio-humeral distance and supraspinatus tendon thickness: test-retest reliability and correlations with shoulder rotational strengths. J Sci Med Sport 2012;15(04):284-291

22 Ruotolo C, Fow JE, Nottage WM. The supraspinatus footprint: an anatomic study of the supraspinatus insertion. Arthroscopy 2004; 20(03):246-249

23 Setiawati R, Rahardjo P, Hartono B. Influence of Weightlifting on the Emergence of Partial and Full Thickness Rotator Cuff Tear Detected by Ultrasound Imaging. Folia Medica Indonesiana 2014; 50(01):52-57

24 Cieminski CJ, Klaers H, Kelly SM, Stelzmiller MR, Nawrocki TJ Indrelie AJ. Total Arc of Motion in the Sidelying Position: Evidence for a New Method to Assess Glenohumeral Internal Rotation Deficit in Overhead Athletes. Int J Sports Phys Ther 2015;10(03):319-331 